\title{
EFISIENSI DOSIS PUPUK NPK MAJEMUK DALAM MENINGKATKAN HASIL KEDELAI VARIETAS GROBOGAN
}

\author{
Panji Setyo Arizka, Niar Nurmauli \& Yayuk Nurmiaty \\ Jurusan Agroteknologi, Fakultas Pertanian Universitas Lampung \\ Jl.Prof. Soemantri Brodjonegoro, No.1, Bandar Lampung 3514 \\ E-mail: panjisetyoarizka@ymail.com
}

\begin{abstract}
ABSTRAK
Pemberian pupuk NPK majemuk yang efisien dalam meningkatkan hasil kedelai sangat penting dalam budidaya kedelai. Penelitian ini bertujuan untuk mengetahui efisiensi dosis pupuk NPK majemuk dalam meningkatkan hasil kedelai varietas Grobogan. Penelitian dilakukan di Kebun Percobaan Terpadu Universitas Lampung dari bulan November 2011-Februari 2012. Rancangan perlakuan adalah tunggal terstruktur bertingkat dalam rancangan kelompok teracak sempurna dengan 3 ulangan. Perlakuan terdiri dari 5 taraf dosis pupuk NPK majemuk yaitu $100 \mathrm{~kg} \mathrm{ha}^{-1}(\mathrm{p} 1), 150 \mathrm{~kg} \mathrm{ha}^{-1}(\mathrm{p} 2), 200 \mathrm{~kg} \mathrm{ha}^{-1}(\mathrm{p} 3), 250 \mathrm{~kg} \mathrm{ha}^{-1}(\mathrm{p} 4)$, dan $300 \mathrm{~kg} \mathrm{ha}^{-1}$ (p5). Homogenitas ragam antarperlakuan diuji dengan Uji Barlett dan nonkemenambahan model melalui Uji Tukey. Jika asumsi analisis ragam terpenuhi, data dianalisis ragam dan pemisahan nilai tengah diuji dengan uji perbandingan ortogonal polinomial. Hasil penelitian didapatkan bahwa setiap penambahan pupuk NPK majemuk $1 \mathrm{~kg} \mathrm{ha}^{-1} \mathrm{justru}_{\text {akan }}$ menurunkan efisiensi pupuk NPK majemuk sebesar 0,029. Pemberian dosis $100 \mathrm{~kg} \mathrm{ha}^{-1}$ sampai dengan $300 \mathrm{~kg} \mathrm{ha}^{-1}$ menunjukkan hasil yang tidak berbeda pada variabel indeks panen, laju pengisian biji, dan bobot 100 butir, sedangkan hasil kedelai meningkat secara linear seiring dengan peningkatan NPK majemuk.
\end{abstract}

Kata kunci: Efisiensi, grobogan, kedelai, pupuk majemuk NPK

\section{PENDAHULUAN}

Kedelai merupakan salah satu komoditas tanaman pangan yang berperan penting dalam pemenuhan gizi masyarakat Indonesia. Kebutuhan terhadap gizi ini dapat diperoleh dari berbagai produk olahan yang berasal dari kedelai. Semua jenis varietas kedelai dapat dikonsumsi dan dapat dijadikan produk olahan makanan. Salah satu varietas kedelai yang dapat dimanfaatkan adalah varietas Grobogan.

Kebutuhan kedelai sangat tinggi di Indonesia, namun produksi kedelai belum mencukupi. Untuk mencukupi kebutuhan kedelai, pemerintah Indonesia memutuskan untuk mengimpor kedelai. Hal ini disebabkan oleh peningkatan produksi lebih rendah dibandingkan dengan peningkatan kebutuhan kedelai. Produksi kedelai tahun 2010 sebesar 905 ribu ton atau menurun 7,13\% dibandingkan dengan tahun 2009 sedangkan kebutuhan kedelai pada tahun 2009 sudah mencapai sekitar 2,3 juta ton (Departemen Pertanian, 2010). Untuk memenuhi kebutuhan kedelai nasional, pemerintah melakukan impor kedelai sebanyak 1,7 juta ton atau senilai 840 juta (Badan Pusat Statistik, 2010).

Pemupukan merupakan salah satu upaya untuk mendapatkan hasil terbaik dari tanaman. Kandungan pupuk yang terdiri dari unsur makro dan mikro dalam dosis tepat dapat meningkatkan efisiensi pemupukan. Menurut Harjadi (2002), efisiensi pemupukan dipengaruhi oleh cara aplikasi, dosis pupuk, waktu aplikasi, dan alat aplikasi.

Salah satu indikator keberhasilan suatu usahatani adalah efisiensi, baik efisiensi teknik budidaya, pengalokasian input maupun output produksi (Sukiyono, 2005). Efisiensi penggunaan pupuk adalah peningkatan produksi untuk setiap satuan pupuk yang ditambahkan (Hernanto, 1995). Berdasarkan hasil penelitian Zahrah (2011), pemberian pupuk NPK organik sebanyak $50 \mathrm{~g} /$ polibag pada tanaman kedelai Varietas Wilis dapat menghasilkan bobot kering biji tertinggi yaitu sebesar 308,26 g/tanaman.

Metode perhitungan efisiensi pupuk dapat digunakan untuk menilai tanaman dalam memanfaatkan unsur hara yang telah diserap dalam menghasilkan produksi lebih tinggi tanpa menambah hara yang diperlukan (Leiwakabessy, 2004). Penggunaan pupuk menjadi efisien bila hasil sebagian besar pupuk yang diberikan diserap tanaman, disebut efisiensi penyerapan. Peningkatan hasil yang besar untuk setiap kg pupuk yang diberikan disebut efisiensi agronomis, (EA).

Penelitian ini bertujuan untuk mengetahui efisiensi dosis pupuk NPK majemuk dalam meningkatkan hasil kedelai Varietas Grobogan. 


\section{BAHAN DAN METODE}

Penelitian ini dilaksanakan di Kebun Percobaan Laboratorium Lapangan Terpadu Universitas Lampung dari Oktober 2011-Januari 2012. Bahan-bahan yang digunakan dalam penelitian ini adalah benih Varietas Grobogan, Pupuk Majemuk Mutiara (16:16:16), Furadan 3G, Dithane 80 WP, dan Decis 2.5 EC. Alat-alat yang digunakan adalah sprayer punggung volume 15 liter, cangkul, tali rafia, meteran, timbangan, label pengamatan, gembor, plastik, cutter, dan alat-alat tulis.

Rancangan perlakuan disusun secara tunggal terstruktur bertingkat dalam rancangan kelompok teracak sempurna yang diulang 3 kali. Perlakuan terdiri dari 5 taraf dosis pupuk NPK yaitu $100 \mathrm{~kg} \mathrm{ha}^{-1}(\mathrm{p} 1)$, $150 \mathrm{~kg} \mathrm{ha}^{-1}$ (p2), $200 \mathrm{~kg} \mathrm{ha}^{-1}$ (p3), $250 \mathrm{~kg} \mathrm{~h}^{-1}$ (p4), 300 $\mathrm{kg} \mathrm{ha}^{-1}(\mathrm{p} 5)$. Homogenitas ragam antarperlakuan diuji degan Uji Barlett dan nonkemenambahan model diuji dengan Uji Tukey. Jika asumsi analisis ragam terpenuhi, data dianalisis ragam pada taraf uji $0,05 \%$ dan pemisahan nilai tengah diuji dengan uji perbandingan ortogonal polinomial.

Sebelum penanaman, dilakukan olah tanah sempurna sebanyak dua kali olah tanah. Tanah diratakan lalu dibuat petak percobaan berukuran $1 \times 2 \mathrm{~m}$ sebanyak 15 petak, sedangkan jarak antarkelompok $100 \mathrm{~cm}$ dengan jarak tanam yang digunakan adalah $30 \times 30 \mathrm{~cm}$. Jumlah benih yang ditanam 2 butir/lubang. Pupuk majemuk Mutiara (16:16:16) diberikan dengan metode larikan sesuai dengan dosis masing-masing perlakuan.

Pupuk diberikan sebanyak dua kali, yaitu pada 1 minggu setelah tanam dan pada 2 minggu setelah tanam. Penyiangan gulma dilakukan secara manual. Pengendalian hama menggunakan insektisida Decis 2.5
EC mengendalikan penyakit tanaman dari kelompok jamur menggunakan fungisida Dithane M-45.

Pengamatan dilakukan pada sampel tanaman yang diambil secara acak dari setiap petak perlakuan (2 sampel tanaman/satuan percobaan). Peubah yang diamati dalam penelitian ini adalah bobot kering berangkasan tanaman, bobot 100 butir, laju pengisian biji, efisiensi pupuk NPK majemuk, indeks panen dan hasil kedelai $\left(\mathrm{t} \mathrm{h}^{-1}\right)$.

\section{HASIL DAN PEMBAHASAN}

Hasil penelitian menunjukkan bahwa pada penelitian ini tanaman kedelai diberi perlakuan pemupukan dari 100-300 $\mathrm{kg} \mathrm{ha}^{-1}$ menunjukkan hasil yang berbeda nyata pada variabel bobot kering berangkasan, effisiensi pemupukan, dan hasil panen sedangkan untuk variabel yang lain tidak berbeda nyata.

Dari hasil penelitian diperoleh bahwa pemberian dosis pupuk NPK majemuk berpengaruh nyata terhadap bobot kering berangkasan, efisiensi pupuk NPK, dan hasil panen. Pemberian dosis pupuk NPK majemuk meningkatkan bobot kering berangkasan secara linier dimana setiap peningkaatan $1 \mathrm{~kg} \mathrm{ha}^{-1}$ pupuk NPK majemuk dapat meningkatkan bobot kering berangkasan sebesar 0,042 gram (Gambar 1). Hal ini menunjukkan pemupukan NPK majemuk sampai dosis $300 \mathrm{~kg} /$ ha belum menghasilkan bobot kering optimum.

Dosis pupuk NPK majemuk yang diberikan juga berpengaruh nyata terhadap efisiensi pupuk secara linear menurun; setiap penambahan pupuk NPK majemuk $1 \mathrm{~kg} \mathrm{ha}^{-1}$ justru akan menurunkan efisiensi pupuk NPK majemuk sebesar 0,029 (Gambar 2). Hasil penelitian ini sesuai dengan penelitian Tayefe et al.,

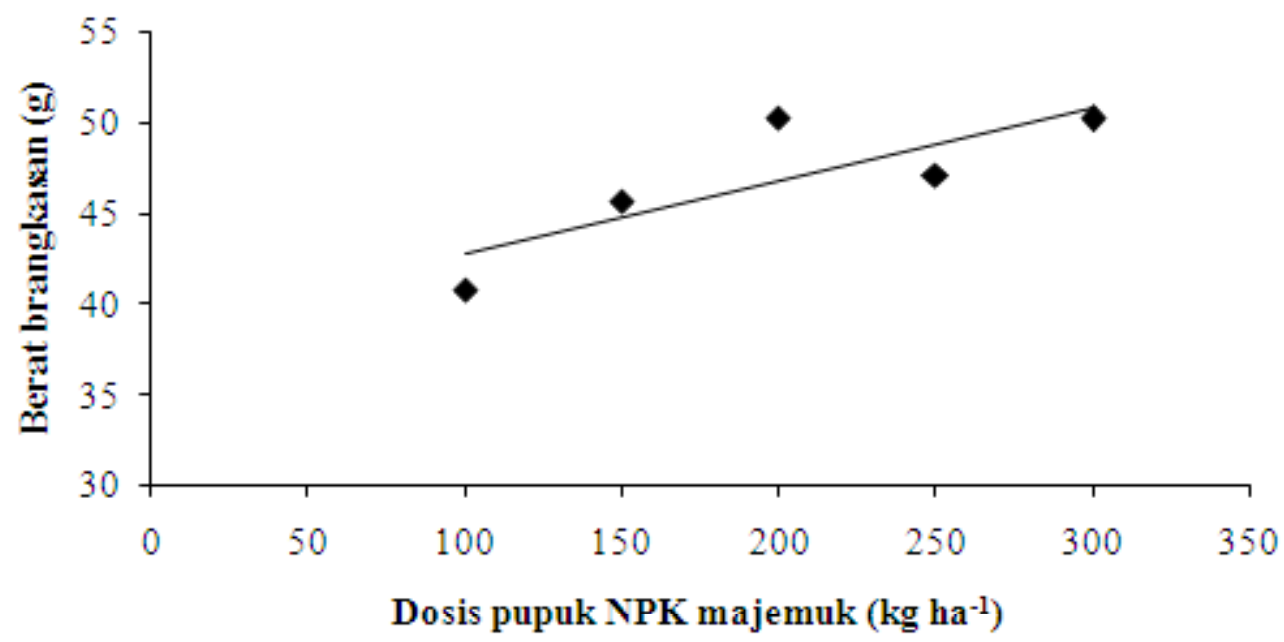

Gambar 1. Hubungan dosis pupuk NPK majemuk dan bobot kering berangkasan. $y=0,042+38,33 ; r=0,082^{*}$ 


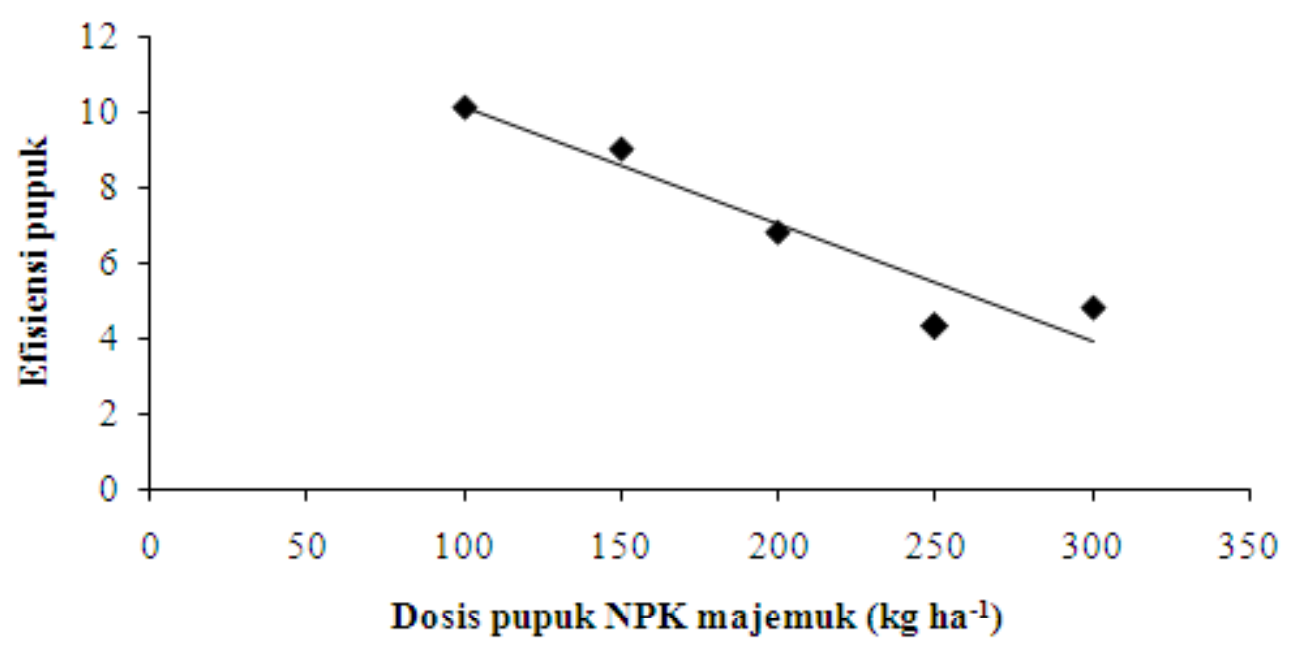

Gambar 2. Hubungan dosis pupuk NPK dan efisiensi pupuk. $y=-0,029+13,14 ; \mathrm{r}=0,902^{*}$

(2011), yang menunjukkan bahwa peningkatan dosis pupuk $\mathrm{N}$ sampai $90 \mathrm{~kg} \mathrm{ha}^{-1}$ pada tanaman padi menurunkan tingkat efisiensi penggunaan nitrogen.

Hasil penelitian Francis et al., (1993), menunjukkan bahwa kehilangan $\mathrm{N}$ pada tanaman jagung sebesar 52-73\% dan kehilangan gas $\mathrm{N}$ tanaman lebih dari $45 \mathrm{~kg} \mathrm{~N}^{-1}$ tahun $^{-1}$ juga telah ditunjukkan pada tanaman kedelai (Stutte et al., 1979 dalam Gordon, 1999). Pupuk $\mathrm{N}$ hilang pada aliran permukaan berkisar antara $1 \%$ dan $13 \%$ dari total $\mathrm{N}$ yang diberikan. Beberapa penelitian pemupukan $\mathrm{N}$ menunjukkan bahwa kehilangan pupuk $\mathrm{N}$ pada tanaman sereal berkisar 20$50 \%$. Kehilangan ini adalah akibat dari kombinasi efek denitrifikasi, penguapan, dan atau pencucian (Franciss et al., 1993). Hal tersebut diduga menjadi faktor yang menyebabkan peningkatan dosis pupuk NPK majemuk, sehingga keadaan ini dapat menurunkan efisiensi pemupukan yang dilakukan.

Pada hasil panen, setiap penambahan $1 \mathrm{~kg} \mathrm{ha}^{-1}$ dosis pupuk NPK majemuk akan meningkatkan hasil panen sebesar 2,2 $\mathrm{kg} \mathrm{ha}^{-1}$. Hal ini sejalan dengan penelitian Hadie et al., (2009) yang menunjukkan bahwa pemberian pupuk NPK hingga $300 \mathrm{~kg} \mathrm{ha}^{-1}$ pada kacang tunggak (Vigna unguiculata [L.] Walp.) berpengaruh pada bobot kering total tanaman dan hasil. Hal ini menunjukkan terjadinya translokasi fotosintat ke organ-organ sink tanaman cukup baik.

Laju pengisian biji menggambarkan peningkatan bobot biji kedelai setiap harinya dan stadium awal pengisian biji kedelai (R5) umumnya mulai terjadi pada umur 65-75 hari, yang ditandai dengan terbentuknya biji sebesar $3 \mathrm{~mm}$ dalam polong pada salah satu dari 4 buku teratas (Arsyad, 1995). Peningkatan dosis pupuk NPK majemuk sampai $300 \mathrm{~kg} \mathrm{ha}^{-1}$ tidak mempengaruhi laju pengisian biji kedelai. Hal ini diduga akibat waktu penghitungan laju pengisian biji yang kurang tepat. Laju pengisian biji dihitung dangan mengukur selisih bobot biji kedelai per tanaman pada umur 12 MST dan 14 MST. Pada umur tersebut, tanaman kedelai sudah tidak melakukan proses pengisian biji kedelai dengan maksimal sehingga penghitungan pada umur tersebut sudah tidak menggambarkan laju pengisian biji yang terjadi pada tanaman kedelai. Hal ini karena pada umur tanaman 70-80 hari (R6), tanaman kedelai mengalami pengisian biji penuh yang ditandai oleh penuhnya rongga polong dengan sebuah biji hijau pada salah satu dari 4 buku teratas pada batang utama (Arsyad, 1995). Pada variabel bobot 100 butir kedelai, perlakuan dosis pupuk NPK majemuk sampai dosis $300 \mathrm{~kg} \mathrm{~h}^{-1}$ menunjukkan hasil yang tidak berbeda, hal ini diduga bobot 100 butir kedelai Grobogan sangat dipengaruhi oleh sifat genetisnya.

Pada penelitian sebelumnya yang dilakukan oleh Ichwan (2009) menunjukkan bahwa peningkatan dosis pupuk NPK majemuk sampai dosis $80 \mathrm{~kg} \mathrm{~h}^{-1}$ susulan pada tananaman kedelai Varietas Grobogan tidak berpengaruh terhadap bobot 100 butir kedelai yang dihasilkan.

\section{KESIMPULAN}

Dari hasil pengamatan dan pembahasan dapat disimpulkan bahwa setiap penambahan pupuk NPK 1 $\mathrm{kg} \mathrm{ha}^{-1}$ justru akan menurunkan efisiensi pupuk NPK majemuk sebesar 0,029. Pemberian dosis $100 \mathrm{~kg} \mathrm{ha}^{-1}$ sampai dengan $300 \mathrm{~kg} \mathrm{ha}^{-1}$ menunjukkan hasil yang tidak berbeda pada variabel indeks panen, laju pengisian biji, dan bobot 100 butir, sedangkan hasil kedelai meningkat secara linear seiring dengan peningkatan NPK majemuk. 


\section{SARAN}

Berdasarkan hasil penelitian yang diperoleh, penulis menyarankan agar menggunakan kontrol sebagai perlakuan dan pengukuran laju pengisian biji dilakukan pada 9 MST dan 11 MST.

\section{DAFTAR PUSTAKA}

Arsyad, D.M. 1995. Kedelai Sumber Pertumbuhan dan Produksi dan Teknik Budidaya. Badan Litban Pertanian. Puslitbang. Bogor. $45 \mathrm{hlm}$.

Badan Pusat Statistik. 2010. http://h0404055. wordpress.com/2010/04/05/manajemenpemupukan-tanaman-kelapa-sawit/. Diaskes pada tanggal 20 September 2011.

Department Pertanian. 2010. http://h0404055. wordpress.com/2010/04/05/manajemenpemupukan-tanaman-kacang-kacangan. Diaskes pada tanggal 20 September 2011.

Francis, D.D., J.S. Scharpers, and M.F. Vigil. 1993. Post-anthesis nitrogen loss from corn. Agron. J. 85:659-663.

Gordon, V.J. 1993. Pupuk Nitrogen. Swadaya. 20 hlm.
Hadie, J., B. Guritno, H.T. Sebayang, dan E. Handayanto. 2009. Pengaruh Pembubuhan Pupuk NPK Terhadap Keragaan Kacang Tunggak dan Karakteristik Pertumbuhan Rhizobium di Lahan Lebak. Agroseintiae 26:1015.

Harjadi, S.S., 2002. Pengantar Agronomi. PT. Gramedia Pustaka Utama. Jakarta. 195 hlm.

Hernanto, 1995. Petunjuk Penggunaan Pupuk. (Edisi Revisi). PT. Penebar Swadaya. Jakarta. 201 hm.

Ichwan, N. 2010. Cara Aplikasi dan Dosis Pupuk NPK Susulan Saat Berbunga dalam Meningkatkan Produksi Kedelai. (Skripsi) Universitas Lampun. Bandar Lampung. $104 \mathrm{hlm}$

Leiwakabessy. 2004. Principle of Seed Science and Technologi Fourth Edition. Norwell. Massachusetts USA.

Sukiyono, 2005. Bertanam Kedelai.Penebar Swadaya. Jakarta. 432 hlm.

Tayefe, M., G. Akif, A. Ebrahim, and N.Z. Azin. 2011. Effect Of Nitrogen Fertilizer On Nitrogen Uptake, Nitrogen Use Efficiency Of Rice. Journal Agronomy:25-27.

Zahrah, S. 2011. Respons berbagai varietas kedelai terhadap pemberian pupuk NPK organik. Jurnal Teknobiologi. II(1):65-69. 